\title{
Ichthyonyms Motivational Analysis: Interdisciplinary Cross-Linguistic Perspective
}

\author{
N. V. Shvets \\ SHEE "Pereiaslav-Khmelnytskyi Hryhorii Skovoroda State Pedagogical University" \\ Corresponding author. E-mail: nathalie.chvets@gmail.com
}

Paper received 09.02.20; Accepted for publication 23.02.20.

https://doi.org/10.31174/SEND-Ph2020-218VIII66-12

\begin{abstract}
The paper presents a complex approach to analysing lexical groups motivation, based on cognitive onomasiological and semasiological perspectives and modern linguistics interdisciplinarity. The author develops a methodology including three successive stages, which allows to analyse lexical groups motivation in all its complexity, paying due consideration to predominant linguistic methods. To illustrate the potential of suggested methodology for conducting cross-linguistic research, the results of analysing one of the lexical groups (English, French and Ukrainian fish names (ichthyonyms)) are given in the paper.
\end{abstract}

Keywords: motivation, semasiology, cognitive onomasiology, interdisciplinarity, fish names.

Introduction. Recent developments in science have led to certain changes in every field, including linguistics, which became more interdisciplinary. Therefore, numerous linguistic studies show signs of involving two or more perspectives, resulting into more profound way to conduct research (M. Matschi [16], M. Napoli \& M. Ravetto [17]); other studies integrate the input of various science fields (N. Dershowitz \& E. Nissan [5], L. Janda [10], O. Rebrii [22]), which enrich linguistics with supplementary information necessary for a thorough analysis.

Literature review. Investigating lexical units and lexical groups motivation is a continuing concern in linguistics. Two main linguistic branches that study this problem are onomasiology and semasiology. They both concentrate on meaning and naming, but from different points of view.

Semasiological approach is chronologically earlier. Fundamental semasiological analyses emerged during the XIX century (H. Paul, K. Reisig) and had been developed throughout the XX century (K. Baldinger, G. Stern). Semasiology (from Greek sēmasiā "meaning" (from sēmainein "to signify")) is defined in modern dictionaries as the branch of linguistics (Oxford Dictionary), another name for semantics (Collins English Dictionary, The American Heritage Dictionary of the English Language), a discipline within linguistics concerned with the question "what does the word $\mathrm{X}$ mean?" (Freebase), the science of the development of the meanings of words (Chambers 20th Century Dictionary). Despite the undefined status (an independent science or a branch of linguistics), it is common to consider its task as studying the lexical meaning of linguistic units and lexical changes.

The opposite of semasiological is onomasiological approach, which was discovered more than hundred years ago (A. Zauner). A variety of definitions of the term "onomasiology" (Greek onomasia "name, expression" (from onomazein "to call, name") has been suggested in the dictionaries: another name for "onomastics" (Collins Dictionary, The American Heritage Dictionary), the branch of linguistics that deals with concepts and the terms that represent them (Oxford Dictionary), the study of words and expressions (MerriamWebster), the branch of semantics concerned with the meanings (Collins English Dictionary). In general, onomasiology is considered to study the naming process for various objects and concepts.

The necessity of an interplay between semasiology and onomasiology was initially pointed out by K. Baldinger [2]. After the definitions analysis, it is clear that both onomasiology and semasiology provide a one-sided view, thus to cre- ate a holistic study these perspectives should be used together.

As mentioned above, linguistic branches tend to interfuse, especially with general scientific approaches. Recently, onomasiology was combined with cognitive aspect (A. Piquer-Pz \& R. Alejo-Gonzz [21]), which placed greater focus on the process of creating words (nomination) that is viewed as cognitive procedure and is an object of investigation of a new linguistic branch - cognitive onomasiology ( $\mathrm{J}$. Grzega [8], P. Koch [13], O. Selivanova [26]).

The aim of the present paper is to propose twodimensional methodology for analysing lexical groups motivation, based on cognitive onomasiological and semasiological approaches and modern linguistics interdisciplinarity.

The mentioned methodology is illustrated by conducting a cross-linguistic research on one of lexical groups, ichthyonyms (from Greek ihth'is "fish"), using the material of three languages: English, French and Ukrainian. The benefits of cross-linguistic studies, which re-emerged and gained importance in recent years (S. Abdulmughni [1], T. Berg [3], E. Lick [15]), include broadening the scope of the study, getting a clearer view of cultural impact on linguistic notions and offering "guidelines to inter-cultural and cross-cultural interaction" (K. Tomaselli [27, p. 377]).

Results and Discussion. Since the objective of this paper is to suggest a complex methodological approach to revealing lexical groups motivation, it seems justified to start with explaining the meaning of the term "motivation" from linguistic point of view.

The literature on motivation shows a variety of approaches to defining it (such as lexical (O. Blinova [4]) and onomasiological (N. Golev [7])), but as this study is a fusion of cognitive onomasiological and semasiological perspectives, the most relevant explanation was proposed by Ukrainian linguist O. Selivanova [26]. The author suggests defining motivation as linguo-cognitive process resulting in the formation of the onomasiological structure projected onto the structure of the knowledge about the designated object [26,p. 109].

In order to explore lexical groups motivation in all its complexity, it is necessary to consider different angles. Therefore, the idea, suggested by German linguist J. Grzega, is relevant to this study: "... the linguist should probe all synonyms that exist for a given concept; he or she should look at the formal qualities of the words and also at the features of the concept; the study should include the entire word field; and it should also include cultural aspects" [8, p. 1038].

Taking all mentioned information into account, we suggest conveying the study of lexical groups motivation in three stages. 
The first stage aims to define the initial motivation of key lexemes in the lexical group.

The second stage focuses on revealing cognitive onomasiological side of motivation, which means finding out the motivational characteristics chosen for each individual unit in lexical group. At this stage, we also analyse the formal qualities of the words, as cognitive onomasiological analysis suggests.

The third stage seeks to uncover semasiological side of the motivation, for this we should find out new uses for lexical units in lexical groups and new meanings that were given to them. In other words, we look at cultural aspects of their use.

Throughout all these stages, the results from three languages are compared (with the help of contrastive method); in such a way, we can talk about similarities or differences in national lexical groups motivation.

The remainder of the paper is organized into three sections, which explain proposed methodology in details and illustrate it by conducting research on English, French and Ukrainian fish names (ichthyonyms).

1. The first stage (defining motivation of key lexemes in the lexical group). When we analyse a certain lexical group, naturally we study all the lexemes that it includes. However, it is also important to analyse key lexemes, which give name to the whole group. Key lexemes commonly have obscure form. Often, we cannot distinguish their motivational characteristics easily, because these lexemes underwent some lexical changes. In such cases, the comparative historical method can be used. This method is based on reconstruction of linguistic phenomena archetypes. In particular, the technique of internal reconstruction helps recreate the forms, which changed in the process of language evolution.

Lexical group "ichthyonyms" has the following key lexemes: fish (in English), poisson (in French) and puбa (in Ukrainian). Their original motivation is revealed with the help of etymological dictionaries.

As stated in Online Etymology Dictionary and Comprehensive Etymological Dictionary of the English Language, English word fish takes roots from Proto-Germanic *fiskaz (also source of German Fisch, Gothic fisks) [18]. The IndoEuropean Etymological Dictionary derives Proto-Germanic *fiskaz from Proto-Indo-European *peisk- (*pisk-) "fish" [9]. As reported by Etymologisches Worterbuch des Deutschen by Pfeifer and Etymologische Wörterbuch der deutschen Sprache by Kluge [12, p. 296], this stem correlates with Proto-Indo-European *peitos- "food".

French lexeme poisson comes from Latin piscis, according to Petit Robert [23, p. 1337] and Petit Larousse [19, p. 796]. Latin word piscis is also derived from Proto-IndoEuropean *peisk- (*pisk-) "fish" (it is stated in The IndoEuropean Etymological Dictionary), so we can assume that English and French key lexemes are of similar origin.

As to Ukrainian риба, Etymological Dictionary of the Ukrainian language compares it to Proto-Slavic ryba, which came from *jryba that is reversal of *jyrba, connected with Proto-Indo-European *ūr- "water" [6, p. 72].

The results of key lexemes reconstruction allow us to talk about common original motivation of English fish and French poisson, which have basic meaning food (PIE *peitos-) and different basis for Ukrainian pиба associated with water as its habitat (PIE *ūr-).

2. The second stage (revealing cognitive onomasiological side of motivation). According to cognitive onomasiological view, to distinguish motivational characteristics used for lexical unit we should find out the motivational basis of each lexeme (which is a group of characteristics that describe certain object). As to fish names, we can find these characteristics in guides for fishermen or biologists. This is when the interdisciplinarity sets in, since we need biological data for conducting linguistic study on fish names. For each lexical group there will be different interdisciplinary connections.

One of the main concerns of cross-linguistic study is to select a basis for analysis, certain component that is able to show the specifics of motivation process (T. Krzeszowski [14]). It seems reasonable to use the motivational characteristic in such a way. When people create words, they choose among a great number of characteristics of some object. The motivational characteristic is the one, which was chosen as a basis for a lexical unit. When we compare these characteristics in different languages, we can talk about not only linguistic side of the choice, but also about some national peculiarities, since language reflects the way of thinking.

After collecting the information from fish guides, we have a set of characteristics for each fish name. For example, in Field Guide to Freshwater Fish by K. Schultz [24, pp. 242243], fish walleye is described with the help of the following characteristics:

shape - has a slender and cylindrical body with a tapered head;

size - 10- to 18-inch range and weighing about 1 to 3 pounds;

body parts - the gill covers and the teeth are sharp; the most prominent feature of a walleye is its large, white, glossy eyes. The special reflective layer in the retina of the eye gathers light that enters the eye, making it extremely sensitive to bright daylight;

colour - colour is highly variable, depending on habitat, with golden colour characteristics;

habitat - the walleye is widely distributed in North America;

breeding time - spawning occurs in the spring or the early summer, depending on latitude and water temperature.

Naturally, the same set of characteristics is applicable to French (doré jaune, literally "golden yellow") and Ukrainian (окунь жовтий "yellow perch") names of this fish species.

One of the steps of nomination is the choice of motivational characteristic, which is accompanied by onomasiological implication (other characteristics extinguishing).

To define the type of motivation of the lexeme, we should reveal the characteristic that was chosen for the name and determine its type. At this stage, we use the model of mental psychonetic complex, developed by O. Selivanova. This model demonstrates the systematic nature of mind, which is organized by the cooperation of various functional modules (propositional, associative and evaluative) with language resources that enables the transformation of information into linguistic form [25, p. 155].

To prove the idea, we should return to our example (fish names walleye, doré jaune and окунь жовтий). After analysing these names and their motivational bases, it is clear that different motivational characteristic was chosen for the name in each language. In English, the name walleye comes from the fact that there is a certain eye shine, which is the result of a light-gathering layer in the eyes that allows the fish to see well at nighttime (a so-called "wall" in the eyes). In French name doré jaune the motivational characteristic "colour" was used in two different ways: directly (jaune 
means “yellow") and metaphorically (doré means "golden"). Ukrainian name окунь жовтий is also created by choosing characteristic "colour" as basis, but it reflects a real feature (жовтий means "yellow"). Apparently, each nation can choose different characteristic for naming the same object, while the same characteristic can be expressed by different language means.

Table 1. Quantitative analysis of English, French and Ukrainian ichthyonyms motivation types

\begin{tabular}{|l|l|l|l|l|}
\hline Motivation types and sub-types & English & French & Ukrainian & Total \\
\hline
\end{tabular}

\begin{tabular}{|l|l|l|l|l|}
\hline Propositional & $\mathbf{2 0 1}$ & $\mathbf{2 4 7}$ & $\mathbf{2 7 7}$ & $\mathbf{7 2 5}$ \\
\hline equonymic & 22 & 9 & 5 & 36 \\
\hline argument-predicate & 179 & 238 & 272 & 689 \\
\hline Associative & $\mathbf{2 3 5}$ & $\mathbf{2 0 5}$ & $\mathbf{9 0}$ & $\mathbf{5 3 0}$ \\
\hline ARTIFACT & 84 & 64 & 26 & 174 \\
\hline ANIMAL & 58 & 56 & 31 & 145 \\
\hline HUMAN & 42 & 43 & 17 & 102 \\
\hline NATURE & 45 & 34 & 12 & 91 \\
\hline UNREAL CREATURE & 6 & 8 & 4 & 18 \\
\hline Evaluative & $\mathbf{1 6}$ & $\mathbf{1 1}$ & $\mathbf{4}$ & $\mathbf{3 1}$ \\
\hline Mixed & $\mathbf{1 8 6}$ & $\mathbf{1 4 0}$ & $\mathbf{7 7}$ & $\mathbf{4 0 3}$ \\
\hline Propositional and Associative & 170 & 95 & 76 & 341 \\
\hline Propositional and Evaluative & 14 & 38 & 1 & 53 \\
\hline Associative and Evaluative & 2 & 7 & - & 9 \\
\hline Total & $\mathbf{6 3 8}$ & $\mathbf{6 0 3}$ & $\mathbf{4 4 8}$ & $\mathbf{1 6 8 9}$ \\
\hline
\end{tabular}

After finding motivational characteristics, we can define the motivation type of each lexeme. The type depends on the mental psychonetic complex module, from which the motivational characteristic was selected. Propositional module includes true information about the object, associative one describes characteristics of the object in terms of other domains, and evaluative one expresses personal view of name creators. Bearing this in mind, we can state that Ukrainian name окунь жовтий is of propositional motivation type as it describes real characteristic directly. French name doré jaune is of associative type, because it represents characteristic "colour" by comparing it to other domain NATURE (metal as natural substance). As to the name walleye, it is also associative one considering that it uses the word "wall" to depict specific characteristic of fish eyes.

In order to identify motivation types of ichthyonyms we studied 1689 fish names (638 - in English, 603 - in French and 438 - in Ukrainian).

The results of cognitive onomasiological analysis are presented in the table below, which contains quantity characteristics of each motivation type.

Table 1 shows that the majority of fish names belongs to propositional motivation type. It can be explained by the fact that this type describes real characteristics of the fish and therefore such names are easy to perceive and remember, as well as create.

Propositional motivation type has certain levels: 1) equonymic (shows connections between fish species); 2) argument-predicate (connected with sublevels of arguments and predicates, quality, quantity and parts). The most represented level in all languages is argument-predicate, since it has various sublevels, which express such information as fish habitat, food, body parts, actions etc.

Associative motivation type is based on different connections between domain FISH and other domains, such as ARTIFACT (English pencil fish, French poisson-flute, Ukrainian риба-меч), ANIMAL (English tiger shark, French poisson-zèbre, Ukrainian сомик панда), HUMAN (English clown fish, French crapet arlequin, Ukrainian бочія клоун),
NATURE (English potato bass, French requin-citron, Ukrainian риба-листок) and UNREAL CREATURE (English goblin shark, French poisson licorne, Ukrainian puбa водяного).

Evaluative motivation type illustrates name creators' attitudes, which are expressed by mentioning positive (English kingfish, French girelle royale, Ukrainian оселедцевий король) or negative (English devil ray, French chimère, Ukrainian риба-химера) images correlating with certain fish species.

If the name has characteristics from two or more modules, it is of mixed motivation type, which has the following subtypes: Propositional and Associative (English sharptooth catfish, French chien espagnol, Ukrainian морський їжак), Propositional and Evaluative (English longnose emperor, French ange de mer africain, Ukrainian акула-ангел європейська), Associative and Evaluative (English giant damselfish, French l'empereur fleuri).

After defining motivation type for English, French and Ukrainian fish names, we discovered similarities and differences in these three languages. The similarities are: 1) the most used motivational characteristic in mentioned languages is fish habitat, as it is one of the most important features in fish description; 2) when associative names are created, visual images from various domains are used most widely, since the majority of information about the fish is perceived visually. There are also certain differences: 1 ) in the English language fish names are often of mixed motivation type, they tend to have two or more motivational characteristics of propositional and associative nature; 2) in Ukrainian and French, associative names cannot be formed with the help of auditive images while they are productive in English (English drum).

At the second stage, according to O. Selivanova [26], we also analysed the formal qualities of the words and found out four structural types of fish names:

1) derivatives (English - 1,1\%, French - 1,1\%, Ukrainian $-11,5 \%)$

2) compounds (English - 20,3\%, French - 10,8\%, Ukrainian - 13,9\%);

3) two-component nouns (English $-72,1 \%$, French $60,6 \%$, Ukrainian $-71,1 \%$ );

4) multi-component nouns (English - 6,5\%, French $27,5 \%$, Ukrainian $-3,5 \%$ ).

3. The third stage (displaying semasiological side of the motivation) is concerned with the development and changes in meaning. We find it reasonable to study the ways in which ichthyonyms can represent different concepts, connotations, and cultural aspects. For this reason, we use linguoculturological analysis. From this point of view, fish names are the basis for creating new meanings with the help of metaphor or metonymy (the result is formation of 223 lexical units (112 - in English, 50 - in French and 61 - in Ukrainian) and phraseological transformation (the result is formation of 110 idioms (26 - in English, 34 - in French and 50 - in Ukrainian).

Lexical units formed from fish names can be grouped into onyms (proper nouns) and appellatives (common nouns).

Proper nouns motivated by ichthyonyms are classified into personal (e.g. English surnames Mackerel, Trout, Bucktrout, French Poisson, Hareng, Languille, Ukrainian Оселедченко, Щучка, Карась) and geographical (e.g. English Sturgeon River, Redfish Lake, French la Rivière aux Brochets, Ukrainian Карасівка, Велика Рибиия) names.

Common nouns created from fish names can denote a 
person (e.g. English loan shark, French hareng saur, Ukrainian акула пера), an object (e.g. English sardine box, French boîte à sardines, Ukrainian puбa "a script"), other animal (e.g. English fish eagle, French poisson d'argent, Ukrainian рибка - an insect) or natural phenomena (e.g. English fishtail wind).

Idioms containing fish names characterize various aspects of a person: human character traits, relationship between people, human being as physical and psychological phenomenon, human behaviour, fortune and misfortune, human emotions and financial situation.

After studying semasiological aspect of English, French and Ukrainian fish names, we determined similarities and differences in these languages. The similarities lie in the fact that in these three languages fish names are used for naming people, rivers and lakes, things and animals, ichthyonyms are also the basis for idioms.

However, some differences were also found. The first difference resides in the disability of French fish names to describe nature. The second difference is the lack of English idioms with fish names for denoting financial situation. As to the Ukrainian and French languages, idioms containing fish names are used to characterize financial situation, especially poverty. Ukrainian people convey the idea of poverty with the help of the fish, which is beating against the ice trying to get back into the water: битися як риба об лід "to struggle desperately for a living". In the French language, the motive of poverty can be expressed through the idioms containing the name hareng. Therefore, the expression vivre d'un hareng means "to have poor nutrition" (literally - to eat only herrings).

It is worth noting that in the idioms mentioned above we can distinctly observe the connection with French and Ukrainian key lexemes archetypical meaning - "water" (in Ukrainian) and "food" (in French). This fact confirms once more, that lexical groups motivation should be revealed on several levels and from different angles to uncover the correlation between the words in the group as well as relations with other lexemes and cultural phenomena.

Conclusions. Summing up the results, it can be concluded that a complex approach to lexical groups motivation allows us to study the material in more effective way, since it takes into account different aspects, such as historical, motivational, formal and cultural ones. The methodology proposed in the article includes three successive stages and combines two linguistic perspectives (cognitive onomasiological and semasiological) with supplementary elements of comparative historical and contrastive methods, it also applies some interdisciplinary data. The suggested methodology is suitable for cross-linguistic research, therefore it enables us to come to certain conclusions about similarities and differences in national way of thinking, to uncover different cultural peculiarities and other aspects of day-to-day life of particular societies.

\section{REFERENCES}

1. Abdulmughni S. Comparison between the Characteristics of Inflectional Systems in Arabic and English Languages. International Journal of English Linguistics. 2017. 7, 1, P. 94-111.

2. Baldinger K. Sémasiologie et onomasiologie. Revue de linguistique romane. 1964. 28. P. 249-272.

3. Berg T. The Semantic Structure of English and German Compounds: Same or Different? Studia Neophilologica. 2016. 88, 2, P. 148-164.

4. Blinova O. Motivology and its aspects. Moscow: KRASAND. 2010. 304 p. (in Russian: Блинова О.И. Мотивология и её аспекты. М.: КРАСАНД. 2010. 304 с.).

5. Dershowitz N. \& Nissan, E. (Eds.). Language, Culture, Computation: Computational Linguistics and Linguistics. Berlin; Heidelberg: Springer-Verlag. 2014. $866 \mathrm{p}$.

6. Etymological Dictionary of the Ukrainian Language]. O. Melnychuk (Ed.). (Vol. 5). Kyiv: Naukova dumka. 1982. 704 p. (in Ukrainian : Етимологічний словник української мови: у 7 т. / [за ред. О.С. Мельничука]. К. : Наукова думка, 2006. Т. 5: Р T. 704 c.).

7. Golev N. Dynamic Aspect of Lexical Motivation. Tomsk: TGU. 1989. 252 p. (in Russian: Голев Н.Д. Динамический аспект лексической мотивации. Томск: Изд-во ТГУ, 1989. 252 с.).

8. Grzega, J. Some aspects of modern diachronic onomasiology. Linguistics. 2002. Volume 40, Issue 5, P. 1021-1045. Available from: https://doi.org/10.1515/ling.2002.035

9. Indogermanisches Etymologisches Wörterbuch. Indo-European Language Revival Association. Retrieved August 12, 2018 from: https://indo-european.info/pokorny-etymologicaldictionary/index.htm

10. Janda L. (Eds.). Cognitive linguistics: The quantitative turn. Berlin; Boston: De Gruyter Mouton. 2013. 321 p.

11. Klein E. A comprehensive etymological dictionary of the English language. (Vol. I). Amsterdam; London; New York: Elsevier Publishing Company. 1966. 854 p.

12. Kluge F. Etymologische Wörterbuch der deutschen Sprache. E. Seebold (Ed.). Berlin; New York: Gruyter. 2002. 1023 p.

13. Koch P. Cognitive onomasiology and lexical change: Around the eye. From Polysemy to Semantic Change. Amsterdam: John Benjamins Publishing Company. 2008. P. 107-137.

14. Krzeszowski T. Contrasting languages: the scope of contrastive linguistics. Berlin: Walter de Gruyter. 1991. P.115-122.

15. Lick E. Multimodality in Canadian print advertising: Different functional connections between headlines and visual texts of advertisements in English and French consumer magazines. Semiotica. 2015. 204, P. 145-172.

16. Matschi M. Color terms in English: onomasiological and semasiological aspects. Onomasiology Online. Vol 5. Retrieved August $12, \quad 2018$ from: http://www1.kueichstaett.de/SLF/EngluVglSW/matschi1041.pdf

17. Napoli, M. \& Ravetto, M. (Eds.). Exploring Intensification. Synchronic, diachronic and cross-linguistic perspectives. Amsterdam; Philadelphia: John Benjamins Publishing Company. 2017. $391 \mathrm{p}$.

18. Online Etymology Dictionary (n.d.). Retrieved August 12, 2018 from: http://www.etymonline.com/

19. Petit Larousse illustré. Paris: Librairie Larousse. 1977. 1790 p.

20. Pfeifer. W. Etymologisches Worterbuch des Deutschen [Etymological Dictionary of German]. W. Klein (Ed.). Berlin; Brandenburg: Academie der Wissenschaften. Retrieved August 12, 2018 from: http://www.dwds.de/

21. Piquer-Pz A. \& Alejo-Gonzz R. Applying Cognitive Linguistics: Identifying some current research foci (figurative language in use, constructions and typology). Review of Cognitive Linguistics, 2016. 1, P. 1-20.

22. Rebrii O. Systemic Approach to Translation: Experimental Research. Advanced Education. 2017. 8. P. 109-114.

23. Robert P. Le Petit Robert: Dictionnaire alphabétique et analogique de la langue française. Paris: S.N.L. 1976. 1971 p.

24. Schultz K. Field Guide to Freshwater Fish. Hoboken: John Wiley \& Sons. 2004. 257 p.

25. Selivanova O. Modern Linguistics: Terminological Encyclopedia. Poltava: Dovkillya-K. 2006. 716 p. (in Ukrainian: Селіванова О.О. Сучасна лінгвістика: термінологічна енциклопедія Полтава: Довкілля-К, 2006. 716 с.).

26. Selivanova Ye. Cognitive onomasiology. Kiev: Fitosotsiotsentr. 2000. 248 p. (in Ukrainian: Селиванова Е.А. Когнитивная ономасиология. К.: Фитосоциоцентр, 2000. 248 c.)

27. Tomaselli K. 'Seeing red': cultural studies in global comparison. Journal of Multicultural Discourses. 2016. 11, 4, P. 375-388. 